\title{
Situation analysis in 3,503 refugees from Mosul to Dohuk and Healthcare in an UNHCR refugee camp in Dohuk
}

\author{
C. Katraschuk1,2, Z. Dudova 1,2, V. Kremery ${ }^{1,2}$, Z. Kuranova ${ }^{1,2}$, J. Benca ${ }^{1,2}$, \\ Y. Trilisinskaya ${ }^{1,2}$, B. Gabrisova ${ }^{1,2}$, O. Petrik',2, P. Ullman ${ }^{1,2}$
}

\section{Original Articles}

${ }^{1}$ B1. Popielusko Jerzy Mobile linic Dohuk SEU Tropical Program and St. Elizabeth

${ }^{2}$ University $\mathrm{PhD}$ and MSc Overseas Projects, Bratislava, Slovakia

\section{Correspondence to:}

Bl. J. Popielusko Mobile Clinic Dohuk, Palackého č. 1, 81000 Bratislava, Slovakia

Submitted: 23.4.2016

Revised: 1.6 .2016

Accepted: 15.8 .2016

\section{Reviewers:}

V. Kozon

Allgemeines Krankenhaus - Medizinischer Universitätscampus, Vienna, Austria

D. J. West

U of Scranton, Department of Health Administration and Human Resources, USA

\section{Key words:}

Refugees, Health.

CSWHI 2016; 7(3): 42-44; DOI 10.22359/cswhi_7_3_11 @ 2016 Clinical Social Work and Health Intervention

\section{Abstract:}

Introduction: The aim of this situation analysis was to compare two phases, acute and post-acute, of disease epidemiology among refugees in the first 6 months (i) and a second 6 months post-acute (ii) period after displacement to an UNNCR camp within the Slovak Field Clinic. Patients and Methods: All together, 3,503 refugees appeared before an humanitarian team at a Mobile Clinic in Dohuk and Sinjar close to the transit border in Northwestern Kurdistan where about 1 million people were displaced after ISIS took over Mosul with its 3 million inhabitants.

Results: In the post-acute period, only 18 cases of diarrhea in four camps is a sign of safe water and high health food standard safety in the designated (UNHCR) camps.

Conclusion: Typical infectious in overcrowded camp populations such gastroenteritis, diarrhea, Hepatitis A, were absent in our group of refugees and migrants. 


\section{Introduction}

The aim of this situation analysis was to compare two phases, acute and post-acute, of disease epidemiology among refugees in the first 6 months (i) and a second 6 months post-acute (ii) period after displacement to an UNNCR camp within the Slovak Field Clinic.

\section{Patients and Methods}

The 3,503 visits appeared before a three person humanitarian team at a Mobile Clinic in Dohuk and Sinjar close to a transit border in Northwestern Kurdistan. There are about 1 million people displaced after ISIS took over of Mosul with its 3 million inhabitants. The spectrum of disease was compared in acute and post-acute periods with a chi-square-test (EpiInfo, CDC) in a univariate analysis.

\section{Results and Discussion}

In the post-acute period, that only 18 cases of diarrhea were found in four designated UNHCR camps in Sinjar is a sign of safe weather and food safety and high public health standards in the camps. Pneumonia ( 40 vs. 32 cases $\mathrm{P}<0,07$ ) was more commonly represented, less than $5 \%$ in both periods; as well as upper RTI despite seasonal weather (242 vs. 110 cases). This difference was significant $(\mathrm{P}<0,01)$ showing surprisingly more RTI in winter (postacute) versus the autumn (acute) period. From other infectious diseases only scabies was represented in several cases in both periods. Of interest was that vaccination status for all patients was complete and well documented. Therefore, after the first case of diphtheria only a surveillance alert was given; in the second period ( 2 of 1,798 vs. 1 of $1,705, \mathrm{P}=\mathrm{NS}$ ) with no severe emergency clinical course, no health alert (8-10) was necessary to declare.

\section{Conclusions}

Due to good sanitary infrastructure supply and safe water (i) and food safety (ii), diarrheal diseases are surprisingly sporadic. The majority of visits were due to upper respiratory tract infections. Scabies from ectoparasitis, was the commonest in this group of displaced refugees in North Kurdistan.

\section{References}

1. ARASON VA, KRISTINSSON KG, SIGURDSSON JA, STEFANSDOTTIR G, MOLSTAD S, GUDMUNDSSON S: Do antimicrobials increase the carriage rate of penicillin resistant pneumococci in children? Cross sectional prevalence study. In BMJ. 1996, August 17, 313 (7054): $387-$ 391

2. HUOVINEN P, MANTTYJARVI R, TOIVANEN P: Trimethoprim resistance in hospitals. In Br Med J (Clin Res Ed). 1982 Mar 13; 284 (6318): 782-784

3. SEPPALA H, KLAUKKA T, VUOPIOVARKILA J, MUOTIALA A, HELENIUS H, LAGER K, HUOVINEN P: 1997 The effect of changes in the consumption of macrolide antibiotics on erythromycin resistance in group A streptococci in Finland. Finish Study Group for Antimicrobial Resistance. NEJ Med. Aug 14; 337(7):441-446

4. KRCMERY V, KALAVSKY E 2007 Antibiotic and antifungal resistance in antibiotic "free" environment? Neuroendocrinology Letters Nov; 28, Suppl 3:33-4

5. GARAU J, NICOLAU DP, WULLT B, BASSETTI M: Antibiotic stewardship challenges in the management of community acquired infectious J Glob. Antimicrob Resist 2, Issue 4, 2014 245-253

6. WICZMANDYOVA D., MURGOVA A, The life of diabetics, life with diabetes, Book. Clear Michalovce ISBN 978-809711629255 2012, pp 67

7. WICZMANDYOVA D, TKACOVA L, MURGOVA M: Proceedings Slov. Med. 
Univ.: The Socio Economic aspect of Migrations ISBN 978-80-89352-47-0, pp.6270

8. SAGAT T: Pediatric sepsis Lekarsky obzor 64, 2015, 2, 51-52

9. SUN YS, ZHAO XY, ZHANG BK, JIANG JF, LU HJ, CAO YX, WU GZ, QIAN J, SUN Y, ZENG YJ: Practices and thinking of laboratory detection in the aid to West Africa to fight against Ebola. Bratislava Medical Journal Vol.117, No.5, p.254-257, 2016. doi:10.4149/BLL_2016_049.

10. B. SILHAROVA, J. SUVADA, M. FRANEKOVA, A. NOGE, G. MIKOLASOVA, Malaria in hyperendemic region, Neuroendcrinology Letters 34, 2013, s1 38-43 